\title{
HOW CONSUMER ENTREPRENEURS \\ ATTAIN POLITICAL LEGITIMACY FOR THEIR EMERGING INDUSTRY: THE CASE OF THE ANTI-FRAUDULENCE INDUSTRY IN CHINA
}

\author{
TIEBING SHI \\ NORTHWEST MisSOURI STATE UNIVERSITY, USA
}

\begin{abstract}
This study examines how consumer entrepreneurs attain political legitimacy for their emerging industry in interaction with the state. An analysis of the discourses made by consumer entrepreneurs who co-created the anti-fraud industry in China between 1994 and 2014 and related discourses made by government officials and journalists was conducted. It finds that, to attain political legitimacy, consumer entrepreneurs in the industry: (1) symbolically integrate the state's evolving dominant political ideologies, values, and agendas into the frames of their practices and collective identities; and (2) adopt five substantive political alignment strategies to help the state achieve its own goals and reinforce its own political legitimacy by collaborating with the central government, the major agent of the state, and challenging some local governments and government regulation agencies. These findings suggest the possibility that legitimation in the market place is a dialectical political process in certain contexts.
\end{abstract}

Keywords: consumer entrepreneurship, political legitimacy, emerging industry, frames, political alignment

\section{Introduction}

Legitimation in the market place has been attracting the attention of consumer researchers for many years. There are three streams of studies 
on this topic in the consumer research literature. The first stream focuses on how consumers legitimize brands or consumption practices (Giesler, 2012; Holt, 2002; Kozinets, 2002; Kozinets \& Handelman, 2004). The second focuses on the legitimation strategies that consumers use to legitimize the market they help expand or create (Scaraboto \& Fischer, 2013; Thompson \& Coskuner-Balli, 2007). And the third focuses on how social factors other than consumers (for example, marketers, journalists) legitimize consumption, a consumption practice, or an industry (Humphreys, 2010a, 2010b; Zhao \& Belk, 2008). Although these extant studies have greatly advanced our understanding about legitimation in the market place, there is a theoretical gap in the literature. How consumer entrepreneurs attain political legitimacy for an emerging industry that they co-create in interaction with the state, which also needs political legitimacy, remains largely uninvestigated.

Filling this gap is critical for consumer research for four reasons. First, the consumers could be profit-making entrepreneurs (Huefner \& Hunt, 1994), and there is a long history that some consumers commercialize their innovations (von Hippel, 2005) and create new industries (Shah \& Tripsas, 2007). Second, acquiring political legitimacy for their industry by legitimizing their products or services, practices, and collective identities is one of the top tasks for the entrepreneurs in an emerging industry (Aldrich \& Fiol, 1994; Navis \& Glynn, 2010). Third, neo-institutional theory (Scott, 2008) suggests that institutional entrepreneurs are not only enabled and limited by various institutions but can also challenge these institutions, and that an established institution (for example, the state) may also need to attain or reinforce its own legitimacy. Fourth, the state via its government's policies impacts the entrepreneurial activities of industries (Minniti, 2008). Due to the popularity of consumer entrepreneurship, the criticality of political legitimacy to entrepreneurs, the dialectical relationship between institutional entrepreneurs and institutions, and the state's impact on entrepreneurial activities, filling this gap may generate new useful knowledge about legitimation in the market place and consumer entrepreneurs.

Drawing on neoinstitutional theory (Scott, 2008), this article aims to theorize how consumer entrepreneurs legitimize the emerging industry they co-create by empirically exploring the legitimation strategies of consumer entrepreneurs in the anti-fraud industry in China between 1994 and 2014 with a netnography methodology (Kozinets, 2002). Specifically, this study intends to answer two research questions: What strategies could consumer entrepreneurs use to gain political legitimacy for their emerging 
industry? How do they interact with the state in their struggle for political legitimacy?

The rest of the article is organized as follows. In the next section, I first review the relevant literatures and then draw on neo-institutional theory to develop the concept of political legitimacy. After that, the methodology is explained and the findings are presented. Finally, the article concludes by discussing the implications, limitations, and directions for future research.

\section{Theoretical Foundation}

\section{Legitimation in the Market place}

There are three streams of studies on legitimation in the market place. The first stream focuses on how consumers legitimize brands and consumption practices. Focusing on moral legitimacy, Kates (2004) finds that gay consumers can use their communal values to legitimize brands of specific marketers. Kozinets and Handelman (2004) find that some consumer activists use certain macrocultural ideologies to frame their collective identities and thereby gain moral legitimacy for their consumption practices.

The second stream focuses on the legitimation strategies that consumers use to legitimize a market they help expand or create, but from which they have no explicit intention to profit. Scaraboto and Fischer (2013) find that the plus-size consumers borrow certain institutional logics of the Fat Acceptance Movement and ally with more powerful institutional actors to legitimize their request for mainstream clothes marketers to provide adequate plus-size fashion. Thompson and Coskuner-Balli (2007) find that the community-supported agriculture consumers and farmers use the logic of community to gain cultural legitimacy for their countervailing market system.

The third stream focuses on how social forces other than consumers legitimize some consumption practices, an industry, or consumption. Humphreys (2010a) and Humphreys and Latour (2013) find that, using cultural and moral values in their frames about casino gambling, journalists influence the cultural and moral legitimacy of casino gambling perceived by consumers. Humphreys (2010b) finds that the firms in the casino gambling industry use both material strategies (that is, using social networks, financial resources, and territorial structures) and rhetorical strategies to gain regulatory, normative, and cultural-cognitive legitimacy 
for their industry. Zhao and Belk (2008) find that advertisers appropriate the state's dominant political ideology to attain political legitimacy for their promotion of consumption in China.

Although these previous studies have admirably enriched our understanding about the impact of cultural and political ideologies on the legitimation strategies of various stakeholders, how the consumer entrepreneurs attain political legitimacy for an emerging industry they co-create in interaction with the state that also needs political legitimacy still remains largely unstudied.

\section{Consumer Entrepreneurship}

While the extant studies on entrepreneurship have extensively examined the ventures formed by university scientists (Stuart \& Ding, 2006) and employees of incumbent firms (Klepper, 2007), consumer entrepreneurship is understudied (Scaraboto \& Fischer, 2013) and cannot be sufficiently explained by the studies on academic and employee entrepreneurship (Shah \& Tripsas, 2007). Based on an extensive review of the literature on entrepreneurship, we can tentatively define consumer entrepreneurship as a process in which the consumers identify and exploit opportunities to generate economic and/or non-economic values for themselves, other consumers, and the society at large by: (1) engaging in innovative consumption practices; (2) offering innovative products and/or services to other consumers and marketers; (3) initiating changes in a related institution or institutions; or (4) combining any of the previous three types of activities. Consumer entrepreneurs are consumers who engage in this entrepreneurial process. They may engage in these activities as a profit-making occupation (Shane \& Venkataraman, 2000) and/or as a free service for public interests. When any of them have an explicit goal to make profits, they may co-create a new industry.

The extant studies on consumer entrepreneurship have explored related profit-making consumption practices (Huefner \& Hunt, 1994), commercialization process (Hienerth, 2006), entrepreneurial process (Shah \& Tripsas, 2007), internet-based consumer entrepreneurship in international business (Chandra \& Coviello, 2010), and consumer-initiated institutional changes (Scaraboto \& Fischer, 2013). Although the extant studies on consumer entrepreneurship and legitimation in the market placemarket place have enriched our understanding of consumer entrepreneurship and consumer entrepreneurs' legitimation strategies, we still lack a theory-based 
understanding of how consumer entrepreneurs attain political legitimacy for the emerging industry they co-create and how they interact with the state. However, neoinstitutional theory offers a helpful lens for us to examine the consumer entrepreneurs' legitimation strategies and relationship with the state.

\section{Political Legitimacy}

New industries need legitimacy to survive and grow, and neoinstitutional theory has been used to study how entrepreneurs gain legitimacy for their emerging industries (Aldrich \& Fiol, 1994; Lounsbury \& Glynn, 2001; Navis \& Glynn, 2010). A new industry is an organizational field that is bounded by a set of institutions. "Institutions are comprised of regulative, normative, and cultural-cognitive elements that, together with associated activities and resources, provide stability and meaning to social life" (Scott, 2008, p.48). Legitimacy is "a generalized perception or assumption that the actions of an entity are desirable, proper, or appropriate within some socially constructed system of norms, values, beliefs, and definitions" (Suchman, 1995, p.574). Due to the dynamics of institutions, legitimation is a dynamic process of attaining and keeping legitimacy (Scott, 2008). Specifically, socio-political legitimation is "the process by which key stakeholders, the general public, key opinion leaders, or government officials accept a venture as appropriate and right, given existing norms and laws" (Aldrich \& Fiol, 1994, p. 648).

Due to our research purpose, this article focuses on political legitimacy related to the state. The state is a regulative institution and has its specific governance structure and dominant political ideologies, values, and agendas (Scott, 2008; Thornton, Ocasio, \& Lounsbury, 2012; Zhao, 2012; Zhao \& Belk, 2008), which impact the entrepreneurs' behaviors and decisions (Minniti, 2008). Following Aldrich and Fiol (1994), Scott (2008), Suchman (1995), and Zhao (2012), we tentatively define political legitimacy of an industry as a generalized perception or assumption that the practices and offerings of an industry and their meanings are congruent with the state's dominant political ideologies, values, and agendas.

Neoinstitutional theory argues that the established institutions also need legitimacy to survive (Scott, 2008). Oliver (1992) argues that when key stakeholders of an institution perceive some problems in the institution's performance levels associated with some institutionalized practices against certain institutionalized evaluation criteria, the institution 
loses legitimacy in the minds of these stakeholders and then weakens and disappears. Accordingly, when the state's major agent, the government is perceived as a low performer by its citizens against some criteria (for example, safe food, good life) promised in the state's dominant political ideologies, values, and agendas, the government loses political legitimacy. Drawing on Scott (2008) and Suchman (1995), we define political legitimacy of the government, as a general perception or assumption that the government's policies and results of the policies are congruent with the state's dominant political ideologies, values, and agendas in the minds of general citizens. We argue that as the legitimacy of new ventures (the agents and key elements of a new industry) affects the legitimacy of the new industry (Aldrich \& Fiol,1994), the political legitimacy of the government, a key agent and element of the state (Scott, 2008; Thornton et al., 2012), also affects the political legitimacy of the state.

Neoinstitutional theory (Scott, 2008) proposes a dialectical relationship between institutional entrepreneurs and surrounding institutions (for example, the state); the surrounding institutions can enable or limit the institutional entrepreneurs, who in turn can challenge or influence these institutions. This relationship implies that some institutional entrepreneurs (for example, certain consumer entrepreneurs) may simultaneously align their practices and the meanings of the practices (which indicate their collective identities) with the state's dominant political ideologies, values, and agendas due to the institutional pressure and challenge, and influence the government and thereby the state in their daily practices. In addition, if the government needs to improve its political legitimacy, it may collaborate with certain institutional entrepreneurs (for example, advertisers) whose practices help it achieve this goal, as the study by Zhao and Belk (2008) implies.

Drawing on neoinstitutional theory, this study aims to examine the strategies used by consumer entrepreneurs to gain political legitimacy in the context of an emerging industry co-created by the consumer entrepreneurs. Specifically, this study considers two research questions: How do consumer entrepreneurs attain political legitimacy for their practices and collective identities, and thereby their emerging industry? How do they interact with the state in their struggle for political legitimacy? 


\section{Methodology}

Because the studied strategies and interactions are sensitive to social, political, and cultural contexts, this study adopts a netnography methodology (Kozinets, 2002), which integrates the internet-based methods with the traditional anthropology methodology (Lin, Guan, \& Knottnerus, 2011; Tian, van Marrewijk, \& Lillis, 2013; Walle, 2016). This study sought a research site where consumer entrepreneurs use diverse strategies to attain political legitimacy for their controversial practices and collective identities in interaction with the state that seeks to reinforce its own political legitimacy. For this purpose, the anti-fraud industry in China was selected.

Since 1978, China has been transiting to an economy that combines central planning and market mechanisms; but, because China lacks well-developed market and legal systems to assure the market mechanism will operate normally, product-quality-related business fraud and corruption are rampant $(\mathrm{Li}, 2004)$. Some companies produce and sell counterfeits and inferior products and release misleading information, while some local government officials protect and seek rent from these companies. In December 1984, China's Consumer Association was established under the guidance of the state's central government, symbolizing the start of the consumer rights protection movement in China. Since then, the central government has issued many laws, regulations, rules, and legal explanations to protect consumer rights. On October 31, 1993, the Consumer Rights Protection Law was passed. According to this law, a fraudulent marketer should compensate a consumer who purchases his counterfeit and inferior products for daily consumption with the value twice that of the consumer's payment. This law created an institutional opportunity enabling the consumers to make a profit by purchasing counterfeits, inferior products, and products promoted with misleading information and then requiring compensation.

In the summer of 1994, relying on the Consumer Rights Protection Law, Guo Zhenqing forced a company to stop its misleading promotion campaign without asking for compensation, initiating the individual-based, not-for-profit, and anti-fraud practices in China. In March 1995, Wang Hai bought 12 counterfeits and got compensation, initiating the individual-based, for-profit, and anti-fraud practices. Since then, many other consumers adopted such individual-based practices as a full- or part-time occupation: some aim to serve the society by not asking for compensation; some aim to profit by buying a huge number of counterfeits 
and inferior products and asking for compensation; and some engage in both for-profit and non-for-profit practices. These entrepreneurial consumers are called professional fraud attackers (PFAs) in mass media. In December 1996, Wang Hai established the first anti-fraud company, profiting by collecting consulting fees from: (1) retailers who tried to avoid selling counterfeits and inferior products or releasing misleading information but lacked the necessary knowledge; (2) producers who tried to avoid releasing misleading information; and (3) producers whose products were copied and who hired his company to investigate and sue the counterfeit producers. Later, many other anti-fraud companies were established. Some PFAs engage in company-based practices only while some engage in both individual- and company-based practices, but most PFAs engage in individual-based practices as individual consumers. In July 1997, 13 leading PFAs co-authored a profession-code-like memorandum for all the PFAs (Wang, Liu, \&Yu, 1997), indicating the birth of the anti-fraud industry.

However, PFAs' practices are controversial in China. In particular, the political legitimacy of these practices is challenged. The Consumer Rights Protection Law does not define what daily consumption means, leading to an institutional opportunity for the fraudulent marketers and the local government regulation agencies protecting these fraudulent marketers. Many fraudulent marketers and local government regulation agencies argue that the PFAs who engage in individual-based, for-profit anti-fraud practices are not true consumers but illegal blackmailers and should not be protected by this law because these PFAs purchase products for making a profit. Some marketers claimed that the PFAs hurt the state's interests because they like to attack big state-owned companies for private interests (Wang et al., 1997). Because state ownership has been a dominant political value in China since 1949, this claim severely hurt the political legitimacy of these practices. In 2005, PFAs were labeled as having "unjustifiable political motivations" (cited from Chen, 2007, p.9). Some officials of the local government regulation agencies which are attacked by the PFAs often label them as unruly people who disturb the social order. In response, the PFAs have to use various strategies to gain political legitimacy for their practices, collective identities, and industry. They do succeed to a certain degree; their industry has expanded. In 2008, there were more than 3,000 PFAs in China.

This industry is perfect for addressing the two research questions because PFAs (1) use diverse strategies to legitimize their practices and identities and thereby their emerging industry; (2) generate extensive discourses in their personal or company's websites, blogs, and interviews 
with journalists, which have rich political implications about consumer entrepreneurship; and (3) are embedded in the largest transitional economy-China, which has been experiencing dramatic changes in its political ideologies, values, and agendas. Thus, this industry provides an excellent context to explore consumer entrepreneurs' legitimation strategies in interaction with the state.

My data collection focused on the discourses of 12 leading PFAs (see Table 1 for details), all of whom are male. This is understandable because the PFAs often face death threats from fraudulent companies (Wang et al., 1997). Data were collected from: (1) the online archives of the blogs of nine PFAs, five PFAs' personal websites, and a PFA's company website; (2) publically available online transcripts of interviews that some journalists conducted with the 12 PFAs; (3) publically available online articles about the consumer anti-fraud movement published in the mass media (for example, the website of the China Consumer News); and (4) three books: Wang Hai's autobiography (Wang et al., 1997), Wang Hai's book that theorizes the industry (Wang, 2000), and Liu Dianlin's biography (Taihangshan, 2014). The leading entrepreneurs' legitimation actions are critical for their emerging industry (Aldrich \& Fiol, 1994); thus, it is proper to focus on the discourses of the 12 leading PFAs.

Table 1: Background Information about the Sample PFAs

\begin{tabular}{|c|c|c|c|}
\hline Name & Age & Anti-fraud Practices & Data Sources \\
\hline $\begin{array}{l}\text { Chen } \\
\text { Shuwei }\end{array}$ & N/A & $\begin{array}{l}\text { Individual-based, for- and } \\
\text { not-for-profit practices }\end{array}$ & $\begin{array}{l}\text { Blog, publically } \\
\text { accessible interview } \\
\text { transcripts, and news } \\
\text { reports }\end{array}$ \\
\hline $\begin{array}{l}\text { Huang } \\
\text { Pingguo }\end{array}$ & 40 & $\begin{array}{l}\text { Individual-based, for- and } \\
\text { not-for-profit practices }\end{array}$ & $\begin{array}{l}\text { Blog, publically } \\
\text { accessible interview } \\
\text { transcripts, and news } \\
\text { reports }\end{array}$ \\
\hline $\begin{array}{l}\text { Huang } \\
\text { Zhihong }\end{array}$ & N/A & $\begin{array}{l}\text { Individual-based, for- and } \\
\text { not-for-profit practices }\end{array}$ & $\begin{array}{l}\text { Personal website, } \\
\text { publically accessible } \\
\text { interview transcripts, } \\
\text { and news reports }\end{array}$ \\
\hline $\begin{array}{l}\text { Feng } \\
\text { Zhibo }\end{array}$ & N/A & $\begin{array}{l}\text { Individual-based, for- and } \\
\text { not-for-profit practices }\end{array}$ & $\begin{array}{l}\text { Personal website, } \\
\text { publically accessible } \\
\text { interview transcripts, } \\
\text { and news reports }\end{array}$ \\
\hline
\end{tabular}




\begin{tabular}{|c|c|c|}
\hline $\begin{array}{l}\text { Lin } \\
\text { Feng }\end{array}$ & N/A & $\begin{array}{l}\text { Individual-based, for- and } \\
\text { not-for-profit practices }\end{array}$ \\
\hline $\begin{array}{l}\text { Liu } \\
\text { Dianlin }\end{array}$ & 61 & $\begin{array}{l}\text { Individual-based, for- and } \\
\text { not-for-profit practices; and } \\
\text { company-based, for-and } \\
\text { not-for-profit practices }\end{array}$ \\
\hline $\begin{array}{l}\text { Sun } \\
\text { Anmin }\end{array}$ & 69 & $\begin{array}{l}\text { Individual-based, } \\
\text { not-for-profit practices }\end{array}$ \\
\hline
\end{tabular}

Wang N/A Individual-based, for- and

Haidong
Wang 41 Individual-based, for- and
Hai not-for-profit practices; and company-based, for-and not-for-profit practices

\begin{tabular}{|c|c|c|}
\hline $\begin{array}{l}\mathrm{Xu} \\
\text { Dajiang }\end{array}$ & 40 & $\begin{array}{l}\text { Individual-based, for- and } \\
\text { not-for-profit practices; an } \\
\text { company-based, for-and } \\
\text { not-for-profit practices }\end{array}$ \\
\hline ar & 3 & $\begin{array}{l}\text { Individual-based, for- and } \\
\text { not-for-profit practices }\end{array}$ \\
\hline
\end{tabular}

Ye Guang
Blog, publically accessible interview transcripts, and news reports

Company's website, biography, publically accessible interview transcripts, and news reports

Blog, personal website, publically accessible interview transcripts, and news reports

Blog, personal website, publically accessible interview transcripts, and news reports

Blog, autobiography, another book by him, publically accessible interview transcripts, and news reports Blog, publically accessible interview transcripts, and news reports

Blog, publically accessible interview transcripts, and news reports

Blog, personal website, publically accessible interview transcripts, news reports, and personal interview 
My data analysis and interpretation followed a constant comparative method to generate themes (Spiggle, 1994). Data was analyzed and interpreted during and after the data collection. Each article in each blog and each personal or company website, each interview transcript, each news report, and each chapter of the three books was analyzed as a unit and compared with old and new articles, interview transcripts, and book chapters to find common themes. In this process, I downloaded new articles and interview transcripts and read new book chapters to seek disconfirming evidence. Data collection, analysis, interpretation, and disconfirming check continued until no new themes emerged and all existing themes were grounded in the data.

\section{Findings}

\section{Theme One: The Politics of Cracking down on Business Fraud}

Rampant product-quality-related business fraud has led to a political legitimacy crisis for the state's central government under the leadership of the Communist Party of China (CPC). Cracking down on business fraud is critical for the central government to reinforce its political legitimacy, a general perception or assumption that the central government's policies and the results of its policies are congruent with the state's dominant political ideologies, values, and agendas which the CPC promotes.

The leaders of the central government understand the political nature of cracking down on business fraud. Business fraud since the 1980s has hurt people's interests and cast doubts on the central government's performance against the CPC's tenet of serving the people. In 1992, the former vice premier Zhu Rongji commented that these business frauds caused "a crisis of trust" and that cracking down on such business fraud was "related to politics, the government's authority and credibility" (Wang et al., 1997, p.26). His comment explicitly points out the political nature of cracking down on business fraud; it is a part of "politics" in terms of common people's general perceptions of the "[central] government's authority and credibility" because business frauds lower the degree of perceived congruence between the central government's performance and the relevant evaluation criteria (for example, serving the people). The crisis which the central government faces is a crisis of political legitimacy in nature, which in turn negatively affects the state's political legitimacy. 
To serve people's interests and to reinforce its political legitimacy, the central government has integrated cracking down on business fraud into its own long-term political agenda. In the spring of 1992 (Wang et al., 1997), the central government has launched a national campaign to crack down on business fraud, established multiple organizations and regulation agencies, and issued various consumer-rights-protection related laws, rules, regulations, and legal explanations. In 2012, Wang Qishan (vice premier since 2008, chair of the national taskforce which is dedicated to cracking down the activities of violating intellectual property rights and producing and selling counterfeits and inferior commodities since 2010), said:

Cracking down on the activities of violating intellectual property rights and producing and selling counterfeits and inferior commodities is a historical task. We should insist on both solving the symptom and removing the roots of the symptom. We should focus on the current situation, emphasize the current period's objectives, pool our resources to solve the problem, show our strength, and safeguard the bottom line of preventing systematic and regional risks. We should have a long-term view, actively improve the methods of removing the roots of the symptom, execute sustainable attacks, truly safeguard people's life and property, safeguard the market order, and safeguard the good images of the party and government. (Quoted from a news report available at http:/www.gov.cn/ldhd/2012-10/ 09/content_2240130.htm)

The above quotation illustrates that cracking down on business fraud has been an essential part of the central government's "long-term" political agenda. Since 1978, building a market economy with Chinese characteristics has been one central goal of the CPC's policies. Although the ideology of the market economy is usually taken for granted in Western countries, the seemingly economic ideology is highly politicized in China, because the shift from its planned economy to a market economy resulted from the political struggle between the reformers such as Deng Xiaoping and some leaders who held to the ideology of planned economy. For leaders such as Wang Qishan, removing business fraud from the market placemarket place is not only a legal or economic issue but also a political task. Doing so displays the party's genuine determination to serve the people and its commitment to build a market economy with Chinese characteristics (that is, "truly safeguard people's life and property" and "the market order"), and thereby reinforces the political legitimacy of the CPC and the central government (that is, "safeguard the good images of the party and 
government"). Mr. Wang's comments and the laws, rules, and regulations, continuously released by the central government since 1992, show that cracking down on business fraud has been integrated into the central government's long-term political agenda and that effectively attacking business fraud could enhance the political legitimacy of the central government and the CPC.

However, some local governments that adopt local protectionism do not follow the central government's agenda, but protect local fraudulent companies, leading to tension between central government and these local governments in the anti-fraud arena. According to Li (2004), some provincial governments protect the local companies that produce counterfeits of famous brands and block cross-provincial anti-fraud activities. The cheaper counterfeits often snatch a significant market share of the authentic brands in the local markets, and even in the national market. Although these provincial governments can collect more tax revenue from local counterfeit producers, central government loses the revenue collected from all provinces due to the shrinking national market share and weakened growth potential of the producers of authentic products. Because local protectionism hurts the national economic performance, central government has tried its best to regulate local governments' behaviors (Zhou, 2007), leading to a power struggle between central local government. The power struggle illustrates the second layer of the political nature of cracking down on business fraud: the existence of fraud is partially due to the weakening of the central government's disciplining power in many fields, a persisting problem which the central government has tried its best to solve (Deng, 2014).

It is in this political environment (where central government seeks to reinforce its political legitimacy and where there is tension between it and local government) that the PFAs strive to legitimize their controversial practices and collective identities, and thereby their industry. As a group, the PFAs understand the politics of cracking down business fraud. Such understanding is universally illustrated in the blog articles of all the 12 PFAs examined in this study, who frequently cite some government leaders' comments on business fraud, and in the PFAs' various strategies to align their practices and collective identities with the central government's goals that embody the state's dominant political ideologies, values, and agendas. 


\section{Theme Two: Attain Collective Political Legitimacy through Collaboration}

Political legitimacy is critical to companies in transition economies where "companies often need to secure the business survival or reduce the regulatory uncertainty" and "political legitimacy is not just a theoretical concept, it is a daily practical concern for many companies" (Zhao, 2012, p.442). Compared with the entrepreneurs in established industries, the entrepreneurs in an emerging industry face greater pressure to gain legitimacy for their industry (Aldrich \& Fiol, 1994). Such pressure has forced the PFAs to exert extra efforts to attain political legitimacy in China.

The PFAs have had their well-planned industry-level legitimation strategies since July 1997, when the 13 PFAs co-authored their industry's first memorandum. In this memorandum, they set up ten rules, including the following ones (Wang et al., 1997, p. 344):

Rule 1: All PFAs should be solidly united, help each other, support each other, and share information with each other.

Rule 2: Protect our team's purity in terms of quality and pay attention to our own images.

Rule 3: Seek broader common grounds while allowing smaller differences, unify our thoughts, improve our understanding, be reasonable and ethical, and have evidences in our anti-fraud practices by following the state's laws and the Party's principles and policies.

Rule 4: Coordinate our actions in our fights against fraud and try our best to attack fraudulent behaviors and safeguard consumers' legal rights.

Rule 5: Build alliances with any forces which we can ally with and keep close contact with organizations and individuals who help and support our cause.

.......

Rule 7: Engage in causes promoting public interests and unselfishly contribute to the society and other consumers as much as possible besides attacking fraud.

Rule 8: Respect all levels of administrative leaders, respect government regulation agencies, and maintain good relations with administrative institutions. 
The above quoted rules suggest that the PFAs were aware of their need for collective political legitimacy and began to engage in coordinated actions to attain political legitimacy for their industry in 1997. First, the frequent use of "we" and "our" indicates the PFAs' early awareness of their need for collective legitimacy. Second, the quoted rules illustrate two guidelines for them to attain collective political legitimacy: all PFAs should: (1) collaborate with each other to attain political legitimacy by aligning their practices and collective identities with the state's dominant political ideologies, values, and agenda (that is, "unifying our thoughts", "following the state's laws, the Party's principles and policies" that embody the state's dominant political ideologies, values, and agendas, "paying attention to our images"); and (2) collaborate with all forces, particularly the state's governments and related regulation agencies (that is, "build alliances", "promoting public interests", "respect...and keep good relations with administrative institutions"). As Aldrich and Fiol (1994) argue that the leading entrepreneurs need to build political legitimacy for their nascent industry, this memorandum co-authored by the 13 leading PFAs illustrates that the PFAs do intentionally build political legitimacy for their industry through collaboration among themselves and with other social forces including the state and its agents.

\section{Theme Three: Politicize Frames of Practices and Collective Identities}

Like the advertisers in the study of Zhao and Belk (2008), the PFAs strategically adapt the frames of their practices and collective identities to the evolving dominant political vocabulary in China. In the history of the CPC, the key terms about its evolving political ideologies, values, and agendas have been integrated in its changing political vocabulary. Since 1944, the political value of serving the people, which came from an essay of Mao Zedong (Mao, 1944), has been the fundamental political tenet of the CPC. In 1978, the CPC started its economic reforms and embraced the ideology of the market economy. In 1992, Deng Xiaoping advocated building a socialist market economy with Chinese characteristics. In 2001, Jiang Zemin (the general secretary of the CPC between 1989 and 2002) proposed that the CPC should represent the fundamental interests of most Chinese people. In 2003, Hu Jintao (the general secretary of the CPC between 2002 and 2012) proposed the view of the Scientific Outlook on Development, which emphasizes people-oriented, comprehensive, coordinated, and sustainable development and building of a socialist 
harmonious society. The main contents of the concept of a socialist harmonious society are democracy and the rule of law, fairness and justice, being honest, etc. In December 2012, Xi Jinping (the general secretary of the CPC since 2012) created the term Chinese Dream, proposing that the CPC and the central government should lead the Chinese people to realize the dream of renewing China and to build a new nation ruled by law. Reflecting the evolving dominant political ideologies, values, and agendas, these terms created by these leaders are continuously added to the CPC's political vocabulary, a key component of the cultural toolkit (Swidler, 1986) for institutional entrepreneurs like the PFAs to tap into when developing their own legitimation discourses.

The PFAs' vocabulary changes with the CPC's political vocabulary, showing the historical impact of the state's evolving dominant political ideologies, values, and agendas on the PFAs' discourses. All the PFAs examined in this study have used some popular political terms available in specific areas in their public discourses. Between 1995 and 2003, the most frequently used political terms in the PFAs' public discourses included socialist market economy, serving the people, market economy, market order, and people's interests. In 2003, the terms Scientific Outlook on Development, harmonious society, and related terms such as scientific development and harmonious community also began to appear in many of the PFAs' public discourses. On March 14, 2014, Wang Hai used the term Chinese Dream as part of the title of his public speech (the PowerPoint document of his speech is available at http://blog.sina.com.cn/s/blog 48d99f720101jx5f.html), arguing that the new regulations about business fraud would advance the latest political agenda of realizing the Chinese Dream and indicating that the PFAs had begun to integrate the latest political agenda into their frames.

Neoinstitutional theory suggests that legitimizing their business practices and collective identity is critical for entrepreneurs to gain legitimacy for a new market segment or a new industry they create (Aldrich \& Fiol, 1994; David, Sine, \& Haveman, 2013; Lounsbury \& Glynn, 2001). Like entrepreneurs in other industries, the PFAs also use some popular political terms to frame their practices, collective identity, and their enemies in their public discourses. For example, Sun Anmin writes in his blog:

China's professional fraud-attackers are a group of brave fighters, legal workers, experts, and woodpeckers who eat borers; they are leaders of the grassroots rights protection movement, helpful assistants to the 
government's functional agencies, the nails in the eyes of the companies who produce, sell...counterfeits, and an indispensable force for societal harmony, peacefulness and safety, regulation, justice, and progress. Regarding their objective impacts, their anti-fraud activities have attacked criminal activities, regulated the market placemarket place, safeguarded laws, protected people, and supported [the principles of] honesty and trust and fair competition. (Sun, 2008)

The above quotation illustrates how PFAs like Mr. Sun skillfully integrate the dominant political vocabulary in China in their frames. For example, Mr. Sun frames his controversial practices as having "objective[ly]" "regulated the market place" (for aligning their practices with the ideology of market economy), "safeguarded laws", "supported [the principles of] honesty and trust and fair competition" (for aligning their practices with the agenda of building a socialist harmonious society), and "protected people" (for aligning their practices with the tenet of serving the people). The quoted terms explicitly align the practices with the value of serving the people, the agenda of building a socialist harmonious society, and the ideology of a free market, which are popular in the state's political vocabulary. In addition, Mr. Sun imaginatively aligns the PFAs' collective identities with the state's political agenda. For Mr. Sun, PFAs, as grassroots fighters, help the state and its government remove borers-like producers and sellers of counterfeits and inferior products (that is, "brave", "legal workers, experts", "woodpeckers", and "helpful assistants to government functional agencies"), and are necessary for the central government to execute its agenda of building a harmonious society (that is, "an indispensable force for societal harmony", "regulation", and "justice").

Specifically, the metaphors of woodpeckers and borers have rich political meanings in contemporary China. First, they are often used to refer to policemen and criminals, respectively. For example, a popular national magazine published by the Ministry of Public Security of China is titled "Woodpecker". The two metaphors are widely used among the PFAs and link the PFAs to the images of policemen who fight against criminals to protect people's lives and interests, implying the similarity between the social functions of the PFAs and police, a popular representative of government regulation agencies. Second, the metaphor of borers has been widely used in the government's discourses to refer to individuals who are against the dominant political ideologies, values, and agendas since the Cultural Revolution. For example, in 2008, a report released on the 
www.xinhuanet.com (the website of the Xinhua News Agency, the official news agency of the central government) refers to corrupted officials as borers of the state ("The Route of Anti-corruption and Checking Power in the Past 30 Years", 2008). Using the two metaphors in their discourses, the PFAs signal that their goals are consistent with the state's goals.

According to Benford and Snow (2004), aligning the frames of their practices and collective identities with the state's dominant political ideologies, values, and agendas makes the practices and identities more easily understandable and acceptable for the state's agents (that is, all levels of government and government regulation agencies). This political alignment is an imaginative political identification with the state (Fligstein, 1997), helping the PFAs attain empathy and political legitimacy from the state.

\section{Theme Four: Substantive Political Alignments}

The PFAs also substantively align their practices with the central government's political agenda by using their own anti-fraud expertise to assist specific government regulation agencies in removing fraud from the market place. Through these substantive alignments, the PFAs directly help reinforce the political legitimacy of the central government and ultimately the political legitimacy of the state. Such strategies have five forms. First, many PFAs, including all the 12 PFAs investigated in this study, pay special attention to fraud in the food and medicine markets, on which central government has focused in recent years. In fact, Huang Zhihong, Wang Haidong, Xu Dajiang, and Ye Guang are leading PFAs in the two markets. In early 2014, Wang Hai said that he would focus on the two markets and planned to earn USD 3.2 million by attacking counterfeit and inferior food and medicines in 2014 (source: http://news.sina.com.cn/ o/2014-02-26/052929564397.shtml). According to Chang and Jia (2011) and Sun (2010), the recent scandals related to food and medicine safety have damaged central government's credibility (or political legitimacy). The central government has continuously introduced new laws, regulations, and policies to improve the product quality in the two markets. By attacking fraud in the two markets, the PFAs strengthen the central government's existing capacity of removing fraud from the two markets and enhance the political legitimacy of their own industry.

Second, many PFAs investigate fraudulent companies independently and report their findings to related government regulation agencies, which 
then take legal action against the companies and give financial rewards to the PFAs. Although such rewards are a source of income for these PFAs, the values of the rewards depend on the specific cases. In many cases, the rewards do not even cover the PFAs' investigation costs. All the PFAs examined in this study have engaged in this form of political alignment. For example, in 2011, Wang Hai (Wang, 2011) reported to the Beijing Administration Bureau for Industry \& Commerce that a global company released a misleading advertisement about one of its product lines sold in China.

Third, the PFAs also engage in non-for-profit activities: (1) they investigate fraudulent companies, purchase a few related products, sue the companies in court, and ask for compensation of low monetary value due to the small number of products bought; (2) they provide free legal aid to consumers through their blogs, personal and/or company websites, telephones, and in special newspapers columns, suggesting how to identify counterfeit and inferior products and misleading information, and how to sue the fraudulent companies; and (3) they act as legal agents in court for some consumers. Their goal is to stop fraudulent behaviors rather than make a profit. All the PFAs examined in this study have engaged in some of these practices. For example, Xu Dajiang sued a telecommunication service company that unfairly overcharged about USD 0.02 , and therefore demanded USD 0.02 compensation (Xu, 2006). This was not economic, ${ }^{1}$ but was legally meaningful to him, as he wanted to demonstrate that consumers could and should use the current legal system to protect their rights and force wrong-doers to change their ways. He won the case, the company altered its practice, and all the other consumers' rights were protected. It is obvious that making a profit was not his goal.

Fourth, some famous PFAs (for example, Ye Guang, Lin Feng, Wang Haidong) work as special partners of certain government regulation agencies. For example, in December 2000, the China Association for Quality Promotion designated Ye Guang as its official investigation agent to protect product-quality-related consumer rights (Ye, 2007). In 2009, Lin Feng was appointed as Specially Invited Law Enforcement Inspector by a branch of the Municipal Administration Bureau for Industry and Commerce of Tianjin City. In the ceremony to grant this title to Mr. Lin, one vice-director of the branch said:

\footnotetext{
${ }^{1}$ Although this type of claim is not that unusual in China.
} 
As a grassroots fraud-attacker, Lin Feng has closely collaborated with the Administration Bureau for Industry and Commerce in past years, [helping us] find and punish many problematic products and companies. These behaviours benefit the society and should be given great support. At the meantime, [we] welcome Lin Feng to report [cases to us] at any time. Starting from today, Lin Feng is a member of our law enforcement department and a fellow soldier in our trench. (Clean Government Space, 2009, "Delivering Anti-Fraud Materials").

The above quotation demonstrates that certain government regulation agencies could even see the PFAs as "member[s]" and "fellow soldier[s]" because the PFAs shared their own professional anti-fraud expertise with these agencies. This means that through such collaboration the PFAs gain approval or political legitimacy for their practices from these government regulation agencies, whose existing capacity of removing fraud from the market place is also enhanced by the PFAs. The government regulation agencies obviously stand for the political authority of the state. Collaborating with these powerful institutions not only helps the PFAs borrow legitimacy from these authoritative partners (Scaraboto \& Fisher, 2013) but also sends a signal to other social actors that stand for other authoritative institutions that these PFAs' practices are consistent with the state's dominant political ideologies, values, and agendas.

Fifth, the PFAs implicitly collaborate with central government by attacking some corrupt local government regulation agencies and emphasizing the locality rather than universality of corruption in the political structure of the state. As noted earlier, there is a power struggle between the central government and many local governments that protect local fraudulent companies (Li, 2004). Specifically, some corrupt local government regulation agencies act as umbrellas fot fraudulent companies to seek rent and to increase the value of the local GDP $(\mathrm{Li}, 2004)$. Attacking these corrupt government regulation agencies by suing them surely helps central government discipline the local governments and enhance its own political legitimacy. All the 12 PFAs investigated in this study have engaged in this type of collaboration with the central government. For example, Huang Zhihong initiated about 1,000 cases and sued at least 213 government institutions, including some local governments and government regulation agencies, between August 2001 and June 2012 (Huang, 2012).

Although the PFAs attack these local government institutions, they strategically frame these local government institutions as only "certain 
government institutions" that are "enemies that hurt the interests of the state and the people" (Sun, 2008). Attacking the local governments and the government regulation agencies, which are parts of the central government, may hurt the political legitimacy of the central government and the state. But, by emphasizing that only "certain" rather than all local governments and government regulation agencies are corrupt, the PFAs avoid challenging the authority of the central government and the state. Also, when they win their cases, they help central government discipline local governments; this is a strong reason why many central government officials publically praised the PFAs' contribution to the country (Wang et al., 1997). Thus, the PFAs engage in a dialectical relationship with the state; while the PFAs collaborate with central government, the major agent of the state, and align the frames of their practices and identities with the state's dominant political ideologies, values, and agendas, they also challenge some parts of central government, certain local governments, and local government regulation agencies.

\section{Discussion}

This paper examines the strategies the consumer entrepreneurs use to attain political legitimacy for their practices and collective identities, and thereby their emerging industry, in the context of the anti-fraud industry in China. Four themes emerge from the data: (1) the politics of cracking down on business fraud; (2) attaining collective political legitimacy through collaboration; (3) politicizing frames of practices and collective identities; and (4) creating substantive political alignments. It is found that the PFAs intentionally integrate the state's dominant political ideologies, values, and agendas into the frames of their own practices and collective identities, and collaborate with central government, that needs to reinforce its own political legitimacy, in five ways: by attacking fraudulent companies in the markets critical for the central government; by investigating fraudulent companies independently and reporting their findings to the related government regulation agencies; by engaging in not-for-profit anti-fraud activities; by working as special partners of certain government regulation agencies; and by attacking specific, corrupted local governments and government regulation agencies and differentiating these local governments and government regulation agencies from the central government and the state. 
This study makes two contributions to consumer research. First, it focuses on how consumer entrepreneurs attain political legitimacy for an emerging industry they co-create. Extant studies on legitimation in the market place have examined how the consumers legitimize their not-for profit, individual or communal consumption practices (Kozinets \& Handelman, 2004) or brands (Holts, 2002; Kates, 2004) and specific markets they help expand or create (Scaraboto \& Fischer, 2013; Thompson \& Coskuner-Balli, 2007), and how the marketers and journalists legitimize a consumption practice and an industry (Humphreys, 2010a, 2010b) and consumption as a whole (Zhao \& Belk, 2008). But how the consumer entrepreneurs attain political legitimacy for the emerging industry they co-create is understudied. Understanding the strategies which the consumer entrepreneurs use to attain political legitimacy for their industry provides insights into the political structure that orients the entrepreneurial consumers' for- and not-for-profit consumption and business practices, and their discourse or frames about their practices and collective identities. Different from the study of Shah and Tripsas (2007) that analyzes consumer entrepreneurship as a social and technological process, this study demonstrates that consumer entrepreneurship can also be a political process where the consumer entrepreneurs actively and dynamically align their practices and collective identities and frames about their practices and collective identities with the state's dominant political ideologies, values, and agendas.

Second, this study investigates one symbolic legitimation strategy and five substantive legitimation strategies that the PFAs use to attain political legitimacy in their dialectical interaction with the state. Extant studies (Giesler, 2012; Humphreys, 2010a, 2010b; Humphreys \& Latour, 2013; Kates, 2004; Kozinets \& Handelman, 2004; Zhao \& Belk, 2008) have examined how the consumers, marketers, and journalists legitimize certain consumption practices, brands, industry, or consumption. However, how the consumers, as institutional entrepreneurs, dialectically interact with the state has not been explored sufficiently. Emphasizing the ideological congruence between the advertisers' frames of consumption and the state's dominant political ideology (that is, advertisers need to follow the institutional order of the state), Zhao and Belk (2008) have proposed that while the advertisers' political construction of consumption has evolved into politicized consumer culture, the governing party has also evoked politicized consumer culture to reinforce the legitimacy of its governance in China, suggesting a collaborative relationship between the advertisers as institutional entrepreneurs and the state. This study explores both the 
collaboration and the confrontation between the consumer entrepreneurs and the state. It finds that the PFAs may both collaborate with central government (the major agent of the state) and challenge some parts of the central government, suggesting a complex relationship between the institutional entrepreneurs like consumer entrepreneurs and the state. In addition, this study analyzes how the internal power struggle of the political structure of the state affects the PFAs' symbolic and substantive legitimation strategies, suggesting that the institutional order of the state might be conflict-ridden in certain historical and geographic contexts and that this internal heterogeneity of institutional order could give institutional entrepreneurs like PFAs an institutional opportunity to ally with some authoritative institutions (for example, the central government in the case of the anti-fraud industry in China) while challenging other authoritative institutions (for example, some irresponsible local governments and government regulation agencies).

This study has several managerial implications. First, it suggests that for an emerging industry, co-created by consumer entrepreneurs, to survive and grow, the pioneering consumer entrepreneurs in this industry should have a collective strategic plan to attain political legitimacy for their business practices and collective identities, which affect the legitimacy of their emerging industry. Second, the consumer entrepreneurs in an emerging industry can use the state's evolving dominant political ideologies, values, and agendas to frame their practices and collective identities to attain political legitimacy to a certain degree. Therefore, these consumer entrepreneurs need to closely track the state's latest dominant ideologies, values, and agendas. Third, this study suggests that the consumer entrepreneurs can collaborate with the state by sharing their own specific expertise with the state's government, helping the government achieve its goals and attaining political legitimacy for their own practices, collective identities, and industry.

Future research could explore the strategies which the consumer entrepreneurs use to attain normative and cultural cognitive legitimacy (Scott, 2008) for an emerging industry they co-create. In addition, this study was conducted in the context of the anti-fraud industry in China; future research could examine the legitimation strategies used by the consumer entrepreneurs in different industries in different countries. Finally, this study focuses on the legitimation strategies of consumer entrepreneurs; future research could simultaneously explore the legitimation and delegitimation strategies of multiple social actors 
involved in an emerging industry, such as consumer entrepreneurs, mass media, relevant government agencies, general consumers, and suppliers.

\section{References}

Aldrich, H.E., \& Fiol, C.M. (1994). 'Fools rush in? The institutional context of industry creation.' The Academy of Management Review, 19(4), 645-70.

Benford, R.D., \& Snow, D.A. (2000). 'Framing processes and social movements: An overview and assessment.' Annual Review of Sociology, 26, 611-39.

Chandra, Y., \& Coviello, N. (2010). 'Broadening the concept of international entrepreneurship: Consumers as international entrepreneurs.' Journal of World Business, 45, 228-36.

Chang, H., \& Jia, Y. (2011, April 27). 'Food safety challenges the government's credibility: Whether nine Departments' co-regulation can avoid "nine dragons administrating raining".' Accessed August 28, 2016. http://fanfu.people.com.cn/GB/14496936.html

Chen, S. (2007, November 6). 'The advocacy for collective accusation by ten thousands of people of one hundred cities.' Accessed August 28, 2016. http://user.qzone.qq.com/119533888

Clean Government Space (2009, May 23). 'The grassroots fraudulence attacker Lin Feng has a "license" to attack business fraudulences.' Accessed August 28, 2016. http://bbs.news.qq.com/t-392363-1.htm

David, R.J., Sine, W.D., \& Haveman, H. A. (2013). 'Seizing opportunity in emerging fields: How institutional entrepreneurs legitimated the professional form of management consulting.' Organization Science, 24(2), 356-77.

Deng, Y. (2014, June 28). 'How to walk out the dilemma that "policies cannot walk out Zhongnanhai”.' Accessed August 28, 2016. http://www.cb.com.cn/opinion/2014_0628/1068852.html.

Fligstein, N. (1997). 'Social skill and institutional theory.' American Behavioral Scientist, 40(4), 397-405.

Giesler, M. (2012). 'How doppelgänger brand images influence the market creation process: Longitudinal insights from the rise of Botox Cosmetic.' Journal of Marketing, 76(6), 55-68.

Hienerth, C. (2006). 'The commercialization of user innovations: The development of the rodeo kayak industry.' R\&D Management, 36, 273-94. 
Holt, D.B. (2002). 'Why do brands cause trouble? A dialectical theory of consumer culture and branding.' Journal of Consumer Research, 29(1), 70-90.

Huang, Z. (2012, June 10). 'Show the administrative institutions I have sued.' Accessed August 28, 2016. http://www.ct315.com/Aiticle.aspx?AId=1091

Huefner, J. C., \& Hunt, H. K. (1994). 'Broadening the concept of entrepreneurship: Comparing business and consumer Entrepreneurs.' Entrepreneurship Theory and Practice, 18(3): 61-5.

Humphreys, A. (2010a). 'Semiotic structure and the legitimation of consumption practices: The case of casino gambling.' Journal of Consumer Research, 37(3), 490-510.

- (2010b). 'Megamarekting: The creation of markets as a social process.' Journal of Marketing, 74(2), 1-19.

Humphreys, A., \& Latour, K. A. (2013). 'Framing the game: Assessing the impact of cultural representations on consumer perceptions of legitimacy.' Journal of Consumer Research, 40(4), 773-95.

Kates, S.M. (2004). 'The dynamics of brand legitimacy: An interpretive study in the gay men's community.' Journal of Consumer Research, 31(2), 455-464.

Klepper, S. (2007). 'Disagreements, spinoffs, and the evolution of Detroit as the capital of the U.S. automobile industry.' Management Science, 53(4), 616-631.

Kozinets, R.V. (2002). 'The field behind the screen: Using netnography for marketing research in online communities.' Journal of Marketing Research, Vol. XXXIX, 61-72.

Kozinets, R.V., \& Handelman, J. M. (2004). 'Adversaries of consumption: Consumer movements, activism, and ideology.' Journal of Consumer Research, 31(3), 691-704.

Li, Y. (2004, September 15). 'Use the Scientific Development View to guide anti-fraudulence activities: The root causes for counterfeits and inferior products to become an enduring social problem and strategies to attack counterfeits and inferior products.' Accessed August 28, 2016. http://www.people.com.cn/GB/ jingji/1045/2786327.html.

Lin, X., Guan, J., \& Knottnerus, J. D. (2011). 'Organizational and leadership practice of micro ethnic entrepreneurship in multicultural context: A structural reproduction analysis.' International Journal of Business Anthropology, 2(2), 48-65. 
Lounsbury, M., \& Glynn, M.A. (2001). 'Cultural entrepreneurship: Stories, legitimacy and the acquisition of resources.' Strategic Management Journal, 22, 545-64.

Mao, Z. (1944). 'Serve the people.' Accessed August 28, 2016. http://baike.baidu.com /subview/81346/ 8567153.htm

Minniti, M. (2008). 'The role of government policy on entrepreneurial activity: Productive, unproductive, or destructive?' Entrepreneurship Theory and Practice, 779-90.

Navis, C., \& Glynn, M. A. (2010). 'How new market categories emerge: Temporal dynamics of legitimacy, identity, and entrepreneurship in satellite radio, 1990-2005.' Administrative Science Quarterly, 55, 439-71.

Oliver, C. (1992). 'The antecedents of deinstitutionalization.' Organization Studies, 13(4): 563-88.

Scaraboto, D., \& Fischer, E. (2013). 'Frustrated fatshionistas: An institutional theory perspective on consumer quests for greater choice in mainstream markets.' Journal of Consumer Research, 39(6), 1234-57.

Scott, R.W. (2008). Institutions and organizations: Ideas and interests. Sage Publications.

Shah, S.K., \& Tripsas, M. (2007). 'The accidental entrepreneur: The emergent and collective process of user entrepreneurship.' Strategic Entrepreneurship Journal, 1(1), 123-40.

Shane, S., \& Venkataraman, S. (2000). 'The promise of entrepreneurship as a field of research.' Academy of Management Review, 25(1), 217-26.

Spiggle, S. (1994). 'Analysis and interpretation of qualitative data in consumer research.' Journal of Consumer Research, 21(3), 491-503.

Stuart, T.E., \& Ding, W.W. (2006). 'When do scientists become entrepreneurs? The social structural antecedents of commercial activity in the academic life sciences.' American Journal of Sociology, 112(1), 97-144.

Suchman, M.C. (1995). 'Managing legitimacy: Strategic and institutional approaches.' Academy of Management Journal, 20(3), 571-610.

Sun, A.M. (2008, January 03). 'Grassroots professional fraudulence-attackers in China.' Accessed August 28, 2016.

http://blog.sina.com.cn/s/blog_44cf8632010084lb.html

Sun, X. (2010, April 1). "“Problematic vaccines" hurt the government's credibility.' Accessed August 28, 2016.

http://www.chinacourt.org/article/detail/2010/04/id/401999.shtml 
Swidler, A. (1986). 'Culture in action: Symbols and strategies.' American Sociological Review, 51(2), 273-86.

Taihangshan. (2014). The north wolves. Beijing: Intellectual Property Publishing House.

Thompson, C. J., \& Coskuner-Balli, G. (2007). 'Countervailing market responses to corporate co-optation and the ideological recruitment of consumption communities.' Journal of Consumer Research, 34(2), $135-52$.

Thornton, P.H., Ocasio, W., \& Lounsbury, M. (2012). The institutional logics perspective: A new approach to culture, structure, and process. Oxford University Press.

Tian, R.G., van Marrewijk, A., \& Lillis, M.P. (2013). General business anthropology. North American Business Press.

Von Hippel, E. (2005). Democratizing innovation. Cambridge, MA: MIT Press.

Walle, A. H. (2016). 'Ethnography: Naturalistic research and business anthropology.' International Journal of Business Anthropology, 6(1), $27-46$.

Wang, H. (2000).An awakening blow: Why we don't think more. Beijing: Beijing Economics Publishing House.

-. (2011, September 6). 'Wang Hai's report: Nike's inferior basketball shoes cheat consumers in the mainland China.' Accessed August 28, 2016. http://blog.sina.com.cn/s/blog_48d99f720100wusn.html

Wang, H., Liu, Y., \& Yu, J. (1997). Wang Hai's autobiography: I am a “Cunny Guy.” Beijing: Writers' Publishing House.

Xinhuanet. (2008, December 15). 'The route of anti-corruption and checking power in the past 30 years.' Accessed August 28, 2016. http://news.xinhuanet.com/politics/2008-12/15/content_10495673.htm

$\mathrm{Xu}, \mathrm{D}$. (2006, November 11). 'The court decided that the QQ gas-station business was fraudulent.' Accessed August 28, 2016. http://80012315.blog.sohu.com/20361122.html

Ye, G. (2007, September). 'Ye Guang's history of attacking fraudulence.' Accessed August 28, 2016. http://www.yeguang315.com/www/site/show.asp?id=42

Zhao, M. (2012). 'CSR-based political legitimacy strategy: Managing the state by doing good in China and Russia.' Journal of Business Ethics, 111, 439-60.

Zhao, X., \& Belk, R. W. (2008). 'Politicizing consumer culture: Advertising's appropriation of political ideology in China's social transition.' Journal of Consumer Research, 35(2), 231-44. 
Zhou, L.A. (2007). 'Governing China's local officials: An analysis of promotion tournament model.' Economic Research Journal, 7, 36-50.

Zhou, Y. (2012, March 21). 'The national party construction in non-publicly-owned enterprises conference was held in Beijing.' Accessed August 28, 2016.

http://news.xinhuanet.com/2012-03/21/c_111685871.htm. 